\title{
RAFAL MICHLIŃSKI
}

ORCID: 0000-0002-6389-2371

\section{Z dziejów wojny polsko-sowieckiej. Uwagi na temat książki: Karol Taube, Figle diablika błot pińskich: ze wspomnień mary- narza, ed. i red. Artur Gajewski, Wydawnictwo Napoleon V, Oświęcim 2018, s. 94}

DOI: $10.15290 /$ sp.2020.28.12

\begin{abstract}
Abstrakt. Wojna polsko-sowiecka miała bezpośredni i ostateczny wpływ na kształt granic II RP. Wyjątkowo specyficznym teatrem działań wojennych był Front Poleski. Ze względu na słabo rozwiniętą infrastrukturę drogową i kolejową, a także skomplikowaną sieć rzek, bagien i mokradeł działania prowadzone były na rzekach - głównie na Pinie, Prypeci, Dnieprze oraz ich dorzeczach. Bezpośrednim uczestnikiem działań na tzw. Morzu Pińskim był por. mar. Karol Taube, który swe wspomnienia z wojny 1919 i 1920 r. zawarł w książce pt. Figle diablika błot pińskich: ze wspomnień marynarza.
\end{abstract}

Słowa kluczowe: Karol Taube, Flotylla Pińska, wojna polsko-bolszewicka, wyprawa kijowska, wspomnienia

Abstract. The Polish-Soviet War largely determined the borders of Second Polish Republic. One of the conflict's fronts, the Poleski Front, was an especially unique theatre of war. Owing to its poor railway and road infrastructure, as well as its complex ecosystem of rivers, marshes and wetlands, the warfare was primarily riverine - taking place on Pina, Pripyat, Dnieper and their tributaries. Sub-Lieutenant Karol Taube, a direct combatant in the military operations on the so-called "Pina Sea", provided an account of the 1919-1920 war in his book Figle diablika błot pinskich: ze wspomnien marynarza [Mischief of the imp of the Pinsk Marshes: a sailor's memoirs].

Key words: Karol Taube, Pinsk Flotilla, Polish-Soviet War, Kiev Offensive, memoirs

Setna rocznica zwycięskiej wojny polsko-bolszewickiej 1920 r. jest doskonałą okazją, by powrócić do początków istnienia II Rzeczypospolitej i pochylić się nad jej skomplikowanymi losami. Tuż po zakończeniu działań Wielkiej Wojny i odrodzeniu się państwa polskiego w 1918 r. rozpoczęła się kolejna wojna, mająca kluczowe znaczenie nie tylko dla ostatecznego wytyczenia granic Polski, ale także dalszego jej istnienia. Ogarnięta rewolucją bolszewicka Rosja rozpoczęła działania wojenne przeciwko Polsce w lutym 1919 r. Teatr działań wojennych rozciągał się od Dyneburga na północy po Kamieniec Podolski na południu. Bezpośrednim świadkiem oraz uczestnikiem wydarzeń wojennych w środkowej jego części - na Froncie Poleskim był por. mar. Ka- 
rol Taube (1888-1940). Zatrudniony w Wojskowym Biurze Historycznym od 1930 r. publikował prace z zakresu marynarki wojennej i historii wojskowości. Współtworzył m.in.: z Olgierdem Żukowskim Zarys historji wojennej flotyll rzecznych (1931), z Romualdem Gintowt-Dziewałtowskim Zarys historji wojennej Pułku Morskiego (1933), z Michałem Sochą Frontem do morza (1934). Wspomniane pozycje obok dzieła Jana Bartlewicza pt. Flotylla pińska i jej udział w wojnie polsko-sowieckiej 1918-1920 (1933) należą kanonu przedwojennych opracowań traktujących o działaniach polskich flotylli rzecznych ${ }^{1}$. Dość powiedzieć, że z dorobku Taubego korzystali także powojenni badacze dziejów tych formacji ${ }^{2}$. W książce zatytułowanej Figle diablika błot pińskich: ze wspomnień marynarza (1937) autor przedstawił swoje wspomnienia z czasu służby we Flotylli Pińskiej. Staraniem oświęcimskiego wydawnictwa Napoleon V w 2018 r. ukazała się reedycja jego wspomnień.

Karol Michał Taube urodził się 8 sierpnia 1888 r. w Krasnogórce na Podolu. Po ukończeniu szkoły powszechnej uczęszczał do szkoły handlowej, którą ukończył w 1909 r. Następnie trafił do Polskiego Seminarium Nauczycielskiego w Ursynowie k. Warszawy. W latach 1909-1911 studiował filozofię na Uniwersytecie we Fryburgu. Od 1912 r. pełnił służbę wojskową w Armii Imperium Rosyjskiego w specjalności saperskiej. Podczas I wojny światowej służył w armii rosyjskiej, w szeregach której przebywał na froncie do kwietnia 1915 r. Od kwietnia do końca października 1916 r. uczęszczał do Szkoły Praporszczyków Admiralicji w Petersburgu i w listopadzie 1916 r. został mianowany praporszczykiem (odpowiednik chorążego). Pełnił też funkcję oficera kompanijnego we Flocie Czarnomorskiej w Mikołajewie.

Po odzyskaniu niepodległości przez Polskę w 1918 r. Taube wrócił do kraju i zgłosił się do nowo utworzonej Marynarki Wojennej. Od marca 1919 r. działał w Sekcji Marynarki Ministerstwa Spraw Wojskowych. Po wybuchu wojny polsko-bolszewickiej 24 kwietnia 1919 r. został skierowany do Flotylli Pińskiej, gdzie wraz z grupą 12 innych marynarzy obsadził pierwsze trzy motorówki („III" „IV" oraz „VI"), a sam został dowódcą motorówki bojowej „IV”. Podczas służby we Flotylli Pińskiej wziął udział m.in. w boju pod Horodyszczem (3 lipca 1919 r.), 17 września 1919 r. walczył pod Petrykowem, a także wziął udział w wyprawie kijowskiej w walkach na Dnieprze. W lipcu 1920 r. został przeniesiony do Flotylli Wiślanej, gdzie objął stanowisko dowódcy IV Dywizjonu i dowódcy motorówki „M-15”. W dniach 18-19 sierp-

1 Zob.: J. Tymiński, Przegląd dorobku polskiej historiografii na temat flotylli rzecznej marynarki wojennej w Pińsku z lat 1919-1939, „Biuletyn Historyczny” 2016, nr 31, s. 23-36.

2 Zob.: J. Dyskant, Flotylla Rzeczna Marynarki Wojennej 1919-1939, Warszawa 1994. 
nia tego roku walczył pod Płockiem. Za wykazane męstwo w walce został odznaczony Krzyżem Srebrnym Orderu Virtuti Militari.

Od kwietnia 1922 r. Taube służył ponownie we Flotylli Pińskiej; na statku sztabowym ORP "Generał Sikorski" pełnił obowiązki komendanta Komendy Portu Wojennego Pińsk. W maju 1924 r. został przeniesiony do Szkoły Specjalistów Morskich w Świeciu. Od kwietnia 1927 r. przeszedł w stan spoczynku w stopniu kapitana marynarki.

Po wybuchu II wojny światowej Taube został powołany do Kierownictwa Marynarki Wojennej. Po agresji sowieckiej 17 września 1939 r. aresztowany przez NKWD znalazł się w więzieniu w Równem. Przewieziony do Kijowa, najprawdopodobniej tam został zamordowany i pochowany na cmentarzu w Bykowni. Należy dodać, że nazwisko Karola Taube znajduje się na tzw. Ukraińskiej Liście Katyńskiej i figuruje pod numerem 41/3-2253.

Wspomnieniowa książka Taubego składa się z siedmiu rozdziałów. Ramy czasowe obejmują okres od 2 lipca 1919 r., tj. od wieczoru poprzedzającego desant polskich oddziałów na Jeziorze Horodyskim i zdobycia wsi Horodyszcze do 11 czerwca 1920 r., czyli momentu samozatopienia okrętu „Pancerny I" w wodach Dniepru. Wspomnienia spisane zostały najprawdopodobniej około 1935 r. Mają charakter retrospektywny - autor często zwalnia narrację wprowadzając opisy poleskiej przyrody, czy też swoje przemyślenia. Zachowany został chronologiczny ciąg wydarzeń. Wyjątek stanowią rozdziały czwarty i piąty (które mogłyby być usytuowane w odwrotnej kolejności), co nie wpływa jednak w istotny sposób na narrację.

W rozdziale pierwszym: Wojna na wodzie Taube opisał okoliczności pierwszego użycia Flotylli Pińskiej i jej „debiutu bojowego" pod Horodyszczem (3 lipca 1919 r.). Początkowo Flotylla wykorzystywana jedynie jako służba transportowa pływała po rzece Strumień, holując materiały wojenne dla polskich oddziałów działających na południowym odcinku Frontu Poleskiego. Jednak z upływem czasu, wraz z opadnięciem poziomu wód na poleskich rzekach, już po rozpoczęciu ofensywy i po licznych namowach marynarzy, dowódca Grupy Poleskiej gen. Antoni Listowski (1865-1927) ${ }^{4}$ zdecy-

3 Szerzej: R. Michliński, Marynarz, pisarz, ofiara Zbrodni Katyńskiej. Karol Taube (1888-1940), [w:] Zapomniane Bandery. Flotylle Rzeczne II Rzeczypospolitej, red. S. Januszewski, Wrocław 2019, s. 199-202. Zob. też: Centralne Archiwum Wojskowe, Akta Personalne Karola Taube 2340, 5250 .

4 Antoni Listowski (1865-1927) generał major Armii Imperium Rosyjskiego, generał dywizji Wojska Polskiego. Uczestnik wojny rosyjsko-japońskiej w latach 1904-1905. W trakcie I wojny światowej walczył na Lubelszczyźnie, Małopolsce i Galicji m.in. 66. Butyrskim Pułku Piechoty, 67. Tarutyńskim Pułku Piechoty i XXXVII Korpusie Piechoty. W czasie 
dował się użyć flotylli do działań bojowych. Autor iście literackim stylem opisuje wyjście marynarzy na Jezioro Horodyskie oraz desant żołnierzy 34. pp i ostateczne złamanie oporu bolszewików.

Rozdział drugi zatytułowany Figle diablika błot pinsskich przedstawia poleskie realia, $\mathrm{w}$ jakich musiał funkcjonować Taube w trakcie służby. Z kolejnych kart książki wyłania się obraz skomplikowanej sieci rzek, kanałów i starorzeczy, którymi oddział bojowy Flotylli Pińskiej pływał patrolując teren. Ukształtowanie terenu, słabo rozwinięte drogi i linie kolejowe, skomplikowana sieć rzeczna oraz podmokłe tereny determinowały wręcz bojowe użycie łodzi na teatrze wojennym Polesia. „Morze Pińskie”, jak były często nazywane rozlewiska poleskich rzek, utrudniało dostęp ku wyznaczonym do opanowania miejscom - przede wszystkim z lądu, ale i z wody. Nie inaczej było i tym razem, gdy Taube opisał próbę dostania się do Ostrowicz, czego potwierdzeniem były słowa, że „najtrudniejszą częścią naszego zadania będzie znalezienie Ostrowicz, które, jak wiemy, leżą gdzieś nad Jasiołdą, i że drogą lądową do nich na razie dotrzeć nie było można" (oddział bojowy miał za zadanie dotrzeć do wsi Ostrowicze i rozbroić bolszewików - uciekinierów spod Horodyszcza). Stare rosyjskie mapy, którymi posługiwała się załoga, okazały się bezużyteczne - autor nazywa ją wprost „śmiesznym papierkiem”, podsumowując zestawienie naniesionych linii na mapę przez "niedbałą rękę urzędnika” z rzeczywistością poleskich mokradeł, formowaną nieobliczalnym żywiołem (s. 16-17). Dzięki pomocy miejscowego Poleszuka niemogący odnaleźć drogi do wsi marynarze przepłynęli przez wskazany kanał i dotarli do celu. Na miejscu okazało się, że nieprzyjaciela już nie było - czerwonoarmiści w sile około 50 ludzi zabrali według relacji mieszkańca pięć najlepszych łodzi i oddalili się Jasiołdą. Tytułowy rozdział nie traktuje o samych działaniach bojowych (zawiera miejscami nawet elementy humorystyczne), a ukazuje czytelnikowi postacie: porucznika Jana Giedroycia oraz nieznanego z imienia, pochodzącego ze Lwowa marynarza Augustyna. Szkoda, że pierwszy dowódca Flotylli Pińskiej, por. Jan Giedroyć (1894-1968) ${ }^{5}$, został zaprezentowany jedynie w kilku krótkich słowach.

wojny polsko-bolszewickiej, w styczniu 1919 r. został dowódcą Grupy Podlaskiej. 3 czerwca 1919 r. został mianowany dowódcą 9 Dywizji Piechoty oraz dowódcą Frontu Poleskiego. Od maja do czerwca 1920 r. dowodził zaś Frontem Ukraińskim. W 1921 r. Listowski przeszedł w stan spoczynku w stopniu generała. Zmarł w Warszawie w $1927 \mathrm{r}$.

5 Jan Bronisław Giedroyć (2 I 1894 -26 XII 1968) - kapitan Polskiej Marynarki Wojennej. Ukończył 7 klas szkoły handlowej w Petersburgu w 1914 r. i wstąpił do Szkoły Marynarki Wojennej. W Rosyjskiej Flocie Bałtyckiej pływał na trawlerach bazujących w Helsinkach. Od 1919 r. służył w Polskiej MW. Był pierwszym dowódcą Flotylli Pińskiej od kwiet- 
Trzeci rozdział zatytułowany Polowanie na kanonierke opisuje wydarzenia mające miejsce po przesunięciu się frontu poleskiego $\mathrm{w}$ połowie sierpnia 1919 r. Mimo braku kontaktu z wrogiem na lądzie, sowieckie okręty nadal ostrzeliwały polskie pozycje oraz placówki, m.in. wieś Turów będącą wówczas miejscem stacjonowania sztabu grupy płk. Grabowskiego. Oddziały grupy poleskiej zostały przemianowane na 9-tą Dywizję Piechoty, a jej dowódcą został płk Władysław Sikorski (1881-1943). Na jego rozkaz, w celu przeciwdziałania Flotylli Dnieprzańskiej, Flotylla Pińska zaczęła patrolować rzekę Prypeć od miejscowości Turów do Pererowa. Podczas jednego z takich patroli, czekając z zasadzką na sowieckie łodzie, po raz kolejny marynarzom dał się we znaki tytułowy "diablik" w postaci Poleszuków, którzy swoim zachowaniem zdradzili polskie pozycje na rzece. Nieudaną zasadzkę Taube wraz ze swoją załogą postanowili powetować wyprawą do Petrykowa (Pietrykowa), gdzie według informacji miała się znajdować baza bojowa Rosjan (obsadzana przez pięciuset żołnierzy). W drodze Taube spotkał się z dowódcą III-go batalionu 34 pp por. K. Galińskim (1894-1939), z którym wspólnie zaplanował atak na wspomnianą miejscowość (17 września 1919 r.). Zadaniem Flotylli Pińskiej był atak na Petryków od strony rzeki oraz zwalczenie stojących tam statków sowieckich. Autor opisał walkę polskich łodzi motorowych z sowieckimi statkami opancerzonymi „Trachtomirow” oraz „Burzyn”. W wyniku wymiany ognia zginął marynarz Doreń. Poza opisem działań Flotylli Pińskiej, a także przedstawieniem sytuacji na froncie południowym, wartościowym fragmentem rozdziału jest ukazanie nastrojów oraz relacji panujących wśród załogi flotylli. $Z$ kolejnych kart wspomnień wyłania się prawdziwy, pozbawiony patosu obraz codziennej służby w marynarce - niesubordynowanych marynarzy wyrażających swoje niezadowolenie z powodu pełnionej służby transportowej oraz braku działań bojowych przeciwko Sowietom ${ }^{6}$. Autor trzeźwym okiem nazwał potencjalną próbę walki z wrogiem więcej niż brawurą, zdając sobie sprawę ze znikomego potencjału bojowego polskich łodzi i motorówek. Dodatkowym ele-

nia 1919 r. Uczestniczył w wojnie polsko-bolszewickiej, walczył na Pinie i Prypeci. Ranny w bitwie pod Łomaczami (13 IV 1919 r.). Przeszedł do rezerwy w $1921 \mathrm{r}$. i rozpoczął pracę w Izbie Skarbowej w Wilnie. W latach 1924-31 służył ponownie w PMW na stanowisku dowódcy torpedowców. W sierpniu 1931 r. został przeniesiony w stan spoczynku w stopniu kapitana i podjął pracę w Lidze Morskiej i Kolonialnej w Wilnie. W latach 1939-45 przebywał w rodzinnym majątku rolnym na Wileńszczyźnie. Od 1945 r. pracował m.in. jako starszy oficer portu w Kapitanacie Portu w Gdyni oraz p.o. naczelnika Wydziału Portów w Gdańskim Urzędzie Morskim. Zmarł bezpotomnie w Gdyni w 1968 r.

6 Por.: I. Bieniecki, Stużba i życie codzienne personelu Flotylli Rzecznej Marynarki Wojennej na Polesiu w latach 1919-1939, „Acta Universitatis Lodziensis. Folia Historica”, 101, 2018, s. 159-173. 
mentem wskazanym w rozdziale była „rywalizacja” marynarzy z wojskami lądowymi, których nazywano wprost "szczurami lądowymi”, oraz niezadowolenie marynarzy z ich bierności bojowej. Taube słusznie zauważa, że w próba wymuszenia dyscypliny siłą przyniosłaby zupełnie odwrotny skutek od zamierzonego. Najważniejszą i najwyżej cenioną cechą, którą przytacza autor wspomnień jest dyscyplina bojowa doświadczonych marynarzy uprzednio służących we flotach zaborczych. Jak wskazuje Taube, samo życie na motorówkach, w niewygodzie i niebezpieczeństwach, wytworzyło zażyły stosunek między oficerami a szeregowymi marynarzami. Jako przykład niech posłużą słowa autora opisującego śmierć marynarza Dorenia: „Naraz sama walka przestała dla mnie istnieć. Życie Dorenia zdało mi się sprawą najważniejszą [...]. Straszna odpowiedzialność za życie podwładnego sparaliżowała we mnie wszelką wolę" (s. 46).

Rozdział czwarty zatytułowany Nasz towarzysz pancerny w zdecydowanej większości traktuje o „Pancernym” (nazywanym także „Pancerny I" i „P I") - okręcie Flotylli Pińskiej - de facto holowniku zdobytym na Sowietach w Barbarowie 5 lub 6 marca 1920 r. (czego niestety autor nie przytacza w swoich wspomnieniach). „Pancerny” (dawniej sowiecki „Trachtomirow”) został wcielony do oddziału bojowego, w skład którego wchodziły motorówki bojowe "M1", „M2" i "M3". Cieszy to, że autor opisując wspomnianego "Pancernego" nie popadł w hurraoptymizm, tak często towarzyszący biorącym udział w walkach żołnierzom i marynarzom. Taube świadomy jego możliwości bojowych nie wychwalał przejętej od wroga łodzi, stwierdzając: „nasz towarzysz to zwykły holownik rzeczny” (s. 47). Daje jednak też upust emocjom, pisząc o „duszy okrętu” i o uczuciach jakimi darzyli „Pancernego" marynarze. Nie brakuje przy tym szczerej dumy, gdyż: ,,jest to przecież pierwszy polski okręt bojowy od czasów floty Władysława IV" (s. 51). Kolejne słowa przytoczone przez autora zdają się najlepszym podsumowaniem znaczenia łodzi: „A to, że musiał walczyć nie na morzu a tylko na rzece i że był trochę zabawny, to bynajmniej nie pomniejszało ideowej wartości w oczach marynarzy" (s. 51). Celne spostrzeżenie może tylko cieszyć czytelnika.

Sformułowanie "było to już po boju pod Łomaczami" (s. 49), a więc 13 kwietnia 1920 r. sugeruje, że kolejny - piąty - rozdział książki pt. Łomacze mógłby być umiejscowiony w książce wcześniej. Nie ma to większego wpływu na ciągłość narracji, jednak nie zachowano porządku chronologicznego opisywanych wydarzeń. Nawiązując do ofensywy na Dnieprze, Taube przedstawił kolejno dotarcie oddziału bojowego Flotylli pod Koszarówkę (26 kwietnia 1920 r.) oraz bój z flotyllą sowiecką pod Czarnobylem. Autor 
poświęcił stosunkowo dużo miejsca samej walce pod Czarnobylem (27 kwietnia 1920 r.), nie zapominając o relacjonowaniu tego, co wówczas działo się na pokładzie „Pancernego". Jest to wielka zaleta tego rozdziału, gdyż bój ten należy do najchwalebniejszych kart polskiej Marynarki Wojennej ${ }^{7}$, a Flotylla Pińska posiadając zdecydowanie mniejszą siłę bojową w porównaniu z Sowietami, zadała nieprzyjacielowi duże straty ${ }^{8}$.

W najkrótszym - piątym rozdziale książki - Taube w literacki sposób przedstawił rozterki i przesądy tęskniącego za morzem i rodzinnym Helem bsmt. Ryczkowskiego oraz bój pod Łomaczami (13 kwietnia 1920 r.). W wyniku natarcia I batalionu 34. pp na pobliską wieś Tulgowicze, atak Flotylli przez zaskoczenie spełzł na niczym i marynarze przystąpili do otwartego ataku. Po zaciętym boju - skrótowo opisanym przez autora - bolszewicy porzucili zajmowane okopy i Łomacze zostały zdobyte. W efekcie wymiany ognia ranni zostali dowódca okrętu por. Giedroyć oraz obserwator ciężkiej baterii por. Szwed, a wspomniany bsmt. Ryczkowski zginął. Ze względu na uprzednio opisywane wydarzenia i boje toczone na Morzu Pińskim przez polską flotyllę, rozdział ten pozostawia pewien niedosyt. Brakuje w nim choćby kilku zdań o przyczynach walki pod Łomaczami (czyli próbie odrzucenia polskich oddziałów za linię rzek Ptycz, Uborć i Słucz). W wyniku odniesionych ran do szpitala trafił por. Giedroyć, którego na stanowisku dowódcy „Pancernego” zastąpił por. Stefan Hryniewiecki (1896-1943). Ta istotna informacja została tu zupełnie pominięta, a sam por. Hryniewiecki - już jako dowódca „pojawił się” (bez słowa objaśnienia) w rozdziale czwartym.

W szóstym rozdziale pt. Pancerna Taube przybliża czytelnikowi charakterystykę motorówki pancernej „MP1” (określanej jako „Pancerna”) i powraca do wydarzeń spod Koszarówki i Czarnobyla. Podobnie jak w poprzednich rozdziałach, autor przedstawia kolejną łódź - MP1 przy pomocy przytoczonych rozmów załogi Flotylli. Dzięki opisowi można zapoznać się z parametrami technicznym „Pancernej” a także z dość powściągliwą opinią jej dowódcy, por. Stefana de Waldena (1896-1976), że „daje tylko osiem kilome-

7 Zob.: J.W. Dyskant, Czarnobyl 1920, Warszawa 1994.

8 Przeciw „Pancernemu”, trzem motorówkom bojowym i jednej motorówce pancernej stanęło do walki sześć opancerzonych statków sowieckich. W trakcie walk na Prypeci na skutek trafienia z „Pancernego" na dno poszedł „Gubitelnyj”. Po tym zdarzeniu sowieci zaczęli odchodzić w stronę Dniepru. Wówczas „Pancerny” oraz „MB III” rozpoczęły pościg, w czasie którego „Pancerny” uzyskał dwa trafienia w okręty „Mudryj” i „Mołodieckij”. Zob.: J. Bartlewicz, Flotylla Pińska i jej udział w wojnie polsko-sowieckiej 1918-1920 (reedycja z 1933 r.), Oświęcim 2013, s. 121-133. 
trów na godzinę, to jest straszne" (s. 67). Nie bacząc na stosunkowo słabe parametry, „Pancerna” uczestniczyła w planowanej ofensywie 9. DP ku Dnieprowi. Uzbrojona w działo górskie $75 \mathrm{~mm}$ zwane „Magdusią" opancerzona motorówka bojowa MP1 wzięła udział w boju pod Koszarówką (24 kwietnia 1920 r.). W towarzystwie motorówek bojowych MB I, MB II oraz MB III „Pancerna” dokonała ataku na sowieckie kanonierki. Celny strzał z „Magdusi" unieruchomił największą spośród czterech, czterodziałową kanonierkę. Sukces operacji był jednak połowiczny, gdyż jak wspomina Taube, wszystkie trzy bojowe łodzie motorowe utknęły na mieliźnie, a celne uderzenie polskiego działa było jedynym, jakie oddała „Pancerna” podczas boju. Flotylla nie poniosła strat, a czerwonoarmiści wzięli na hol swoją uszkodzoną łódź i udali się w dół rzeki.

Siódmy, a zarazem ostatni rozdział - Ostatni bój "Pancernego" w swojej pierwszej części przedstawia wyjście łodzi z Kijowa. „Pancerny” po wysadzeniu desantu złożonego z żołnierzy 1. pp Leg. pod Witaczowem przybył 4 czerwca 1920 r. do Kijowa. Postój jednak nie trwał długo, gdyż na wieść o naprawieniu przez Sowietów mostu na Dnieprze między Okuniowem a Stracholesiem i zorganizowaniu drugiej przeprawy biało-czerwona flotylla ponownie wyruszyła w bój. Fakt ten spotkał się z ostrym sprzeciwem mechanika bsm. Szpringera, który zdając sobie sprawę z pogarszającego się stanu technicznego „Pancernego" (m.in. połamane łopaty) żądał remontu łodzi i jednodniowego postoju. Mimo usilnych starań rozkaz por. Hryniewieckiego o wypłynięciu został utrzymany. Taube po raz kolejny $\mathrm{w}$ trafny sposób przedstawia i podsumowuje trudne realia służby w nowo powstającym polskim wojsku: „Był to tylko wynik ostrego zetknięcia sumiennego fachowca wychowanego $\mathrm{w}$ terrorze porządku niemieckiej marynarki, z polską wojenną rzeczywistością, w której panowała improwizacja. [...]. Stary żołnierz niemiecki czuł się w takiej atmosferze bardzo niepewnie" (s. 80). Podobne spostrzeżenia stanowią istotną wartość książki.

W dalszej części rozdziału Taube opowiada o boju toczonym z bolszewikami w okolicy przeprawy. Oprócz sowieckich łodzi „Pancerny” będący w coraz gorszym stanie technicznym rozpoczął walkę z jeszcze jednym "przeciwnikiem" - mieliznami. Trudne warunki dały się we znaki zdeterminowanym marynarzom, jednak tym razem szczęście, o którym często pisał Taube, opuściło Flotyllę Pińską. Rozluźnione nity, przeciekające burty oraz uszkodzenie działa spowodowały, że "Pancerny" wycofał się z boju o dolny bieg Prypeci. Krótka wzmianka o ponownym natarciu okrętu o świcie przy ujściu Teterewa stanowi zakończenie książki. Wlewająca się na pokład woda i kończąca się amunicja są ostatnimi wspomnieniami, którymi dzieli się autor 
z walk wojny polsko-bolszewickiej. Opis idącego na dno na skutek samozatopienia "Pancernego" (11 czerwca 1920 r.) kończy wspomnienia dowódcy grupy motorówek Flotylli Pińskiej.

Wspomnienia Karola Taube, mimo swojej niewielkiej objętości, posiadają bezcenną wartość. Relacje bezpośredniego uczestnika wojny polsko-bolszewickiej dają nam unikatowe spostrzeżenia prosto z pokładu pierwszych łodzi bojowych flotylli, a także poszerzają dotychczasową wiedzę o wspominanych wydarzeniach. Celne spostrzeżenia, pozbawione patosu i koloryzowania wywody autora pozwalają zweryfikować wyobrażenia i osądy o okolicznościach tworzenia jednego z oręży II RP - Polskiej Marynarki Wojennej. Obok niezwykle interesujących wydarzeń Taube porusza także trudne tematy: trudności zaopatrzeniowych oraz improwizacji wymuszonej brakiem uzbrojenia, dyscypliny marynarskiej braci ${ }^{9}$, czy relacji z lokalną ludnością.

Książkę oczywiście trudno uznać za pozbawioną pewnych uchybień. Brak dziennych dat przy opisywanych wydarzeniach oraz niezachowanie chronologii stanowią najistotniejsze $\mathrm{z}$ nich. Licznie przytaczane rozmowy pomiędzy autorem wspomnień a członkami załogi - są trudne do weryfikacji pod kątem ich autentyczności. Kilka zabiegów poczynionych przez edytora z pewnością wpłynęłoby pozytywnie na atrakcyjność reedycji Figli... Na pewno biogram Karola Taubego byłby znaczącym uzupełnieniem książki.

Wydarzenia opisywane przez autora aż proszą się o dodatkowe opracowanie graficzne i mapy, które byłyby dużym ułatwieniem dla zilustrowania działań Flotylli na „Morzu Pińskim”. Dodatkowe przypisy edytorskie stanowiłyby świetne uzupełnienie miejscami lakonicznych wypowiedzi autora. W tekście pojawiły się także błędy literowe (s. 59, 77, 90, 92). Pierwsze wydanie Figli ukazało się w 1937 r., a nie jak podano w stopce wydawniczej w 1935 r. Pomimo to warto sięgnąć po wspomnienia Karola Taubego. Napisana przystępnym językiem relacja bezpośredniego uczestnika wydarzeń, chłodne osądy i celne spostrzeżenia na temat otaczającej rzeczywistości (nie tylko wojennej) poszerzają naszą wiedzę o trudnych początkach nowo powstałego państwa polskiego i Flotylli Pińskiej ${ }^{10}$.

9 Zob.: A. Ochał, Problemy żandarmerii Korpusu Ochrony Pogranicza z Marynarzami Flotylli Pińskiej w 1927 r. Przyczynek do historii formacji w świetle dokumentów żandarmerii KOP , „Przegląd Historyczno-Wojskowy" 2018, nr 3-4, s. 98-113.

10 Por.: A. Drzewiecki, Flotylle rzeczne w strukturze i planach obronnych II Rzeczypospolitej, [w:] Zapomniane Bandery..., s. 345-356. 


\section{Bibliografia}

Centralne Archiwum Wojskowe, Akta Personalne Karol Taube 2340, 5250.

Bartlewicz J., Flotylla Pińska i jej udział w wojnie polsko-sowieckiej 1918-1920 (reedycja z 1933 r.), Oświęcim 2013.

Bieniecki I., Służba i życie codzienne personelu Flotylli Rzecznej Marynarki Wojennej na Polesiu w latach 1919-1939, „Acta Universitatis Lodziensis. Folia Historica”, 101 (2018).

Drzewiecki A., Flotylle rzeczne w strukturze i planach obronnych II Rzeczypospolitej, [w:] Zapomniane Bandery. Flotylle Rzeczne II Rzeczypospolitej, red. S. Januszewski, Wrocław 2019.

Dyskant J.W., Czarnobyl 1920, Warszawa 1994.

Dyskant J.W., Flotylla Rzeczna Marynarki Wojennej 1919-1939, Warszawa 1994.

Michliński R., Marynarz, pisarz, ofiara Zbrodni Katyńskiej. Karol Taube (1888-1940), [w:] Zapomniane Bandery. Flotylle Rzeczne II Rzeczypospolitej, red. S. Januszewski, Wrocław 2019.

Ochał A., Problemy żandarmerii Korpusu Ochrony Pogranicza z Marynarzami Flotylli Pińskiej w 1927 r. Przyczynek do historii formacji w świetle dokumentów żandarmerii KOP, „Przegląd Historyczno-Wojskowy” 2018, nr 3-4.

Taube K., Figle diablika błot pińskich: ze wspomnień marynarza, ed. i red. Artur Gajewski, Oświęcim 2018.

Taube K., Socha M., Frontem do morza, Warszawa 1934.

Taube K., Żukowski O., Zarys historji wojennej flotyll rzecznych, Warszawa 1931.

Tymiński J., Przegląd dorobku polskiej historiografii na temat flotylli rzecznej marynarki wojennej w Pinsku z lat 1919-1939, „Biuletyn Historyczny” 2016, nr 31.

Zarys historji wojennej Pułku Morskiego, oprac. R. Dziewałtowski-Gintowt, K. Taube, Warszawa 1933.

From the history of the Polish-Soviet War. Comments on Karol Taube's book Figle diablika błot pińskich: ze wspomnień marynarza [Mischief of the imp of the Pinsk Marshes: a sailor's memoirs], ed. Artur Gajewski, Napoleon V, Oświęcim 2018, p. 94

\section{Summary}

Karol Michał Taube (1888-1940): originally a soldier of the Imperial Russian Navy, following Poland's restoration of independence, he began his service in the Polish Navy in spring of 1919 and fought in the Polish-Soviet War on the Poleski Front. After his retirement from the service in 1927, he worked at the Military History Department. Taube published his memoirs from the Polish-Soviet War for the first time in 1935 in the book Figle diablika błot pińskich: ze wspomnien marynarza [Mischief of the imp of the Pinsk Marshes: 
a sailor's memoirs]. The book is a personal account of the conflict narrated by Taube, a direct combatant on the Poleski Front and the Kiev Offensive. The author's judgments and keen observations inspire the reader to reflect upon the circumstances surrounding the formation of the Pinsk Flotilla and the first years of its service. The author, without unnecessary pathos, narrates the skirmishes on the "Pina Sea", introduces the crewmen, sailor customs and superstitions, and describes the ships. The narrated events and obstacles encountered by the newly formed military formation - the Pina Flotilla, are a testament to the author's - a captain of one of the flotilla's speedboats - maturity and literary talent.

Rafał Michliński - pracownik Instytutu Pamięci Narodowej, do jego głównych zainteresowań badawczych należą historia Flotylli Pińskiej oraz dzieje Kresów Wschodnich II RP. e-mail: rafal.michlinski@gmail.com 